\title{
Izabela Ścibiorska-Kowalczyk
}

Uniwersytet Ekonomiczny we Wrocławiu

\section{Jarosław Kowalczyk}

Akademia Sztuk Pięknych we Wrocławiu

\section{OCHRONA WŁASNOŚCI INTELEKTUALNEJ W OBSZARZE KOMUNIKACJI WIZUALNEJ}

\begin{abstract}
Streszczenie: Celem artykułu jest ukazanie specyficznych problemów związanych z naruszeniem własności intelektualnej w obszarze komunikacji wizualnej oraz próba wskazania skuteczniejszych sposobów jej ochrony. Ochrona prawna utworów z obszaru komunikacji wizualnej nie daje gwarancji poszanowania własności intelektualnej. Orzecznictwo napotyka problemy, u podstaw których leży uznaniowy charakter oceny oryginalności utworów artystycznych. W artykule przedstawiono studia przypadków, które ilustrują ten stan w sposób dobitny. Wielu twórców nie wchodzi na drogę prawną w wypadku plagiatu ich projektów ze względu na niepewny efekt postępowania i kłopotliwy, a bywa, że i kosztowny proces. W przypadku naruszenia cudzej własności intelektualnej w odniesieniu do utworów należących do obszaru komunikacji wizualnej zasadnicze znaczenie ma postawa projektanta. Bardzo istotne są również okoliczności, w których dochodzi do naruszenia własności intelektualnej. Analiza tych okoliczności stanowić może punkt wyjścia do poszukiwania skutecznych sposobów zapobiegania przypadkom naruszenia własności intelektualnej, ze szczególnym naciskiem na wskazanie iluzorycznych korzyści z tego tytułu, uzyskiwanych w tak specyficznej dziedzinie, jaką jest komunikacja wizualna. Zaproponowano więc możliwe kierunki działań w celu ograniczenia praktyki naruszania własności intelektualnej. Analiza tych działań została oparta na koncepcji poszukiwania maksimum korzyści możliwych do osiągnięcia we współpracy projektanta z zamawiającym. Z przeprowadzonych analiz poszczególnych sytuacji wynika wniosek, że projektant osiąga maksymalną korzyść w przypadku, gdy zrealizuje on w pełni oryginalny projekt, powstały w rezultacie odpowiednio długiego i prowadzonego z należytą starannością i wnikliwością procesu projektowego. Odpowiednio silne zaangażowanie emocjonalne w projekt stwarza również szansę na unikalny efekt artystyczny. Taki projekt uprawnia twórcę do odpowiednio wysokiego wynagrodzenia oraz dostarcza mu możliwości promocji i uzyskania kolejnych atrakcyjnych zleceń. Zamawiający osiąga maksymalną korzyść w sytuacji, gdy otrzyma unikalny, wartościowy pod względem artystycznym projekt dający podstawę do skutecznych działan marketingowych. W wysokim potencjale projektu należy upatrywać możliwości zwrotu poniesionych na niego nakładów. Dziedzina komunikacji wizualnej wchodzi w okres kształtowania się wzorców zachowań, również etycznych. W dobie rosnącej konkurencji zaczynają się liczyć nie tylko talent i kompetencje artystyczne projektanta, ale również preferowany przez niego modelowy proces projektowy oraz opinia $\mathrm{w}$ środowisku. Jest też miejsce na ocenę etyczności zachowań projektantów i włączenie tej oceny w proces ich wyboru przez zamawiającego. Postawa projektanta ma bowiem kluczowy wpływ na unikanie sytuacji naruszenia cudzej własności intelektualnej.
\end{abstract}


Równie istotna jest właściwa relacja między projektantem a zamawiającym. Trendem gospodarczym powoli staje się personalizacja produktu z maksymalnym dostosowaniem go do indywidualnych potrzeb klienta. Ten kierunek będzie prowadził do znacznego zwiększenia się unikatowych projektów, wymuszając na systemie prawnym uproszczenie procedur rejestracji i skuteczności egzekwowania prawa autorskiego. Znajdzie to prawdopodobnie również odzwierciedlenie w ustawie odpowiedzialnej za znaki towarowe - co może pozwalać w sposób pozytywny patrzeć w przyszłość ochrony własności intelektualnej w obrębie komunikacji wizualnej.

Słowa kluczowe: własność intelektualna, komunikacja wizualna, prawa autorskie, znaki towarowe.

DOI: $10.15611 / \mathrm{e} 21.2014 .2 .06$

\section{Wstęp}

Przywłaszczenie własności intelektualnej w odniesieniu do produktów z obszaru komunikacji wizualnej poprzez jej skopiowanie z istniejącego już pierwowzoru nie budzi jeszcze w społeczeństwie podobnego potępienia jak zawłaszczenie przedmiotu prowadzące do fizycznej jego utraty przez prawowitego właściciela. Ten stan wymaga wielu lat przebudowy świadomości i modyfikacji wzorców etycznych. Niezbędne jest powszechne przeświadczenie, że autor jako twórca oryginalnego rozwiązania wkłada w nie określoną ilość energii i zaangażowania. Za danym projektem stoją często godziny analiz, badań, prób wydestylowania esencji danego zagadnienia. Dodatkowo elementy komunikacji wizualnej to projekty jednostkowe, czyli całkowicie spersonalizowane na potrzeby klienta. W tym momencie skopiowanie danego rozwiązania, bez wniknięcia w jego istotę i źródło powstania, powoduje znaczące obniżenie jego intelektualnej wartości. Obserwowanie, jak własny projekt zostaje okrojony i „spłycony”, może prowadzić do frustracji.

Prawo własności intelektualnej obejmuje dość szeroki zakres tematyczny. Najczęściej wskazuje się na: patenty, prawa ochronne obejmujące wzory przemysłowe, znaki towarowe (własność przemysłowa), prawa autorskie i prawa pokrewne. Celem artykułu jest ukazanie specyficznych problemów związanych z naruszeniem własności intelektualnej w obszarze komunikacji wizualnej oraz próba wskazania skuteczniejszych sposobów jej ochrony. Wskazano przy tym, że specyfika dziedziny stwarza szczególne możliwości zapobiegania przypadkom naruszenia własności intelektualnej, a ochrona prawna jest tylko jednym ze środków, w praktyce niezbyt skutecznym.

W przypadku naruszenia cudzej własności intelektualnej w odniesieniu do utworów należących do obszaru komunikacji wizualnej zasadnicze znaczenie ma postawa projektanta. Ponieważ naruszenie własności następuje już na etapie projektu, to projektant jest odpowiedzialny za taką sytuację. Bardzo istotne są również okoliczności, w których dochodzi do naruszenia własności intelektualnej. Analiza tych okoliczności stanowić może punkt wyjścia do poszukiwania skutecznych sposobów za- 
pobiegania przypadkom naruszenia własności intelektualnej, ze szczególnym naciskiem na wskazanie iluzorycznych korzyści z tego tytułu, uzyskiwanych w tak specyficznej dziedzinie, jaką jest komunikacja wizualna. Kluczowe znaczenie ma tutaj relacja między projektantem a zamawiającym.

Należy także wspomnieć o szkodach, które czynione są poprzez kradzież dóbr intelektualnych. Oczywiście w pierwszej kolejności są to szkody materialne, kiedy autor traci oryginalny pomysł, za który inny podmiot uzyskuje korzyści finansowe. Dlatego całość ochrony prawnej nastawiona jest na tę właśnie rekompensatę.

\section{Pojęcie prawa własności intelektualnej}

Pojęcie prawo własności intelektualnej, czy też prawo na dobrach niematerialnych, odnosi się do wszelkich wytworów ludzkiego umysłu, jak i praw do korzystania z nich ${ }^{1}$. Wartości intelektualne tworzone są przez człowieka, który dzięki wyobraźni i zdolności oraz czasami, gdy jest to niezbędne, za pomocą urządzeń i procesów technologicznych jest $\mathrm{w}$ stanie wytworzyć pewien materialny lub niematerialny efekt. Tak więc prawo własności intelektualnej można uznać za zespół norm regulujących zachowania społeczne wobec indywidualnych, dotychczas niespotykanych przejawów umysłu ludzkiego, czego efektem jest powstanie oryginalnego dzieła w sferze kultury duchowej lub materialnej [Michniewicz 2012]. W oparciu o obowiązujące ustawodawstwo do prawa własności intelektualnej zaliczamy [Załucki 2008]:

1. Prawo własności literackiej, artystycznej i naukowej, w tym:

- prawo autorskie, które reguluje i chroni przede wszystkim prawa do dzieła (utworu),

- prawa pokrewne, dotyczące m.in. artystycznych wykonań, fonogramów czy nadań, odnoszące się przede wszystkim do podmiotów, dzięki którym utwory są rozpowszechniane,

- ochronę baz danych, dotyczącą zbiorów danych i innych materiałów i elementów zgromadzonych według określonej systematyki lub metody.

2. Prawo własności przemysłowej, obejmujące ochronę dóbr niematerialnych, które można wykorzystać do przemysłowego zastosowania lub eksploatacji:

- prawo projektów wynalazczych, czyli rozwiązań technicznych wykazujących zdolność przemysłowego zastosowania, w tym: prawo patentowe, prawo wzorów przemysłowych, prawo wzorów użytkowych, prawo typografii układów scalonych,

- prawo oznaczeń odróżniających, dotyczących regulacji prawnych do oznaczeń związanych z działalnością gospodarczą, w tym: prawo znaków towarowych, prawo oznaczeń geograficznych.

3. Prawo dotyczące zwalczania nieuczciwej konkurencji, m.in. zwalczania nieuczciwych praktyk rynkowych, w tym ochrony prawnej w relacjach business-to-business oraz business-to-consumer.

\footnotetext{
${ }^{1}$ Zob. strona internetowa projektu: [Popularyzacja wiedzy z zakresu...].
} 
Przedmiotem prawa autorskiego jest każdy przejaw działalności twórczej o indywidualnym charakterze, ustalony w jakiejkolwiek postaci, niezależnie od wartości, przeznaczenia i sposobu wyrażenia (utwór) [Ustawa z dnia 4 lutego 1994 r. ..., art. 1, ust. 1]. Aby wytwór niematerialny mógł zostać uznany za utwór w rozumieniu prawa autorskiego, powinien wykazywać następujące cechy (zob. [Sieńczyło-Chlabicz $i$ in. 2009; Barta $i$ in. 2005]):

- Utwór powinien być rezultatem pracy człowieka, co jednoznacznie oznacza, że twórcą musi być tylko człowiek, czyli nie mogą to być np. osoby prawne i jednostki organizacyjne nieposiadające osobowości prawnej.

- Utwór powinien być przejawem działalności twórczej i mieć indywidualny charakter, o oryginalności dzieła można mówić, gdy istnieje subiektywnie nowy wytwór intelektu, a działalnością twórczą jest działalność, której rezultatem jest wytwór intelektualny, który może być uznany za nowy, wzbogacający istniejący stan rzeczy.

- Utwór powinien mieć indywidualny charakter, co oznacza, że dzieło (utwór) powinno wyróżniać się od innych takich samych przejawów działalności twórczej w taki sposób, aby świadczyło o jego oryginalności i innych właściwościach, które nadają mu cechy niepowtarzalności i wskazują, że w przeszłości nie było takiego samego utworu [System prawa... 2007]

- Utwór powinien być ustalony ${ }^{2} \mathrm{w}$ dowolnej postaci.

Prawo autorskie jest częścią prawa własności intelektualnej zawierającą przepisy wydane z myślą o ochronie interesów twórców i dotyczy stosunków prawnych związanych z tworzeniem utworów, korzystaniem z nich i ich ochroną [Zajączkowski 2003].

\section{Znaki towarowe jako ochrona praw własności w obrębie komunikacji wizualnej}

Wybranym zakresem w obrębie ochrony praw autorskich jest obszar komunikacji wizualnej. Obszar ten jest o tyle interesujący z punktu widzenia ochrony własności intelektualnej, że jest najbardziej rozbudowany, gdyż wszelka komunikacja marketingowa na linii producent-odbiorca (B2C), producent-producent (B2B) odbywa się właśnie za pomocą środków wizualnych. Nawet jeżeli najważniejszym elementem jest przekaz merytoryczny, to jest on prezentowany w formie komunikatu wzrokowego. Jak łatwo się domyślić, przy takiej skali działalności i ilości informacji spory odnoszące się do prawa autorskiego muszą nastąpić. Całego zagadnienia nie da się opisać bez zaprezentowania podstawowego narzędzia chroniącego podmioty, czyli znaków towarowych.

${ }^{2}$ Ustalenie utworu jest to jego „uzewnętrznienie”, które umożliwia percepcję utworu przez osoby trzecie, inne niż twórca, dokonane w jakiejkolwiek postaci (może to być np. wykonanie improwizacji muzycznej, wyrecytowanie wiersza, wygłoszenie referatu) - zob. [Barta i in. 2005]. 
„Znakiem towarowym może być każde oznaczenie przedstawione w sposób graficzny lub takie, które da się w sposób graficzny wyrazić, jeżeli oznaczenie takie nadaje się do odróżniania w obrocie towarów jednego przedsiębiorstwa lub rodzaju towarów innych przedsiębiorstw. Znakiem towarowym może być w szczególności wyraz, rysunek, ornament, kompozycja kolorystyczna, forma przestrzenna, w tym forma towaru lub opakowania, a także melodia lub inny sygnał dźwiękowy" [Ustawa $z$ dnia 30 czerwca 2000 r. ..., art. 120, ust. 1 i 2$].$

Podstawowy podział znaków towarowych, uwzględniający ich formę i zastosowanie, wyróżnia:

- oznaczenia słowne (wyraz, zdanie slogan),

- słowno-graficzne (oznaczenia, w których występują zarówno elementy słowne, jak i graficzne),

- graficzne (rysunki, ornamenty).

Jednak tego typu podział do zastosowań prawnych jest zbyt mało szczegółowy, stąd wprowadzono dodatkowe kategorie znaków towarowych:

- przestrzenne (w tym forma towaru lub opakowania),

- dźwiękowe (melodie i sygnały dźwiękowe),

- przestrzenno-słowno-graficzne,

- przestrzenno-graficzne.

\section{Znaki towarowe}

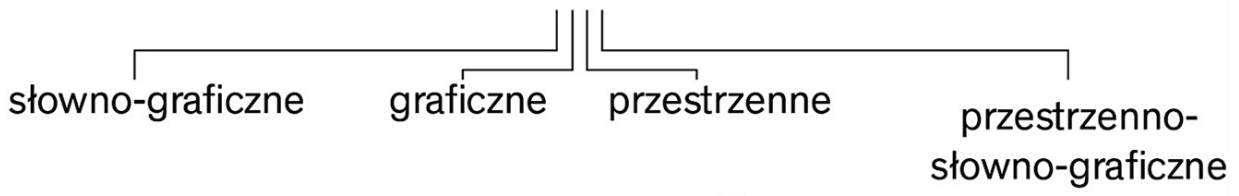

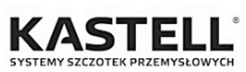

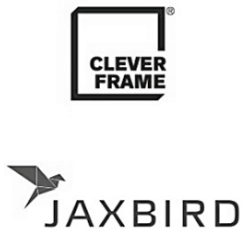

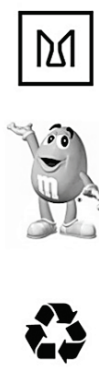

equedeh

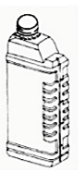

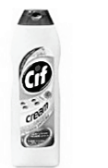

Rys. 1. Podział znaków towarowych wraz z przykładami

Źródło: opracowanie własne.

Prawo ochrony znaku towarowego można nabyć na różne sposoby, w różnych systemach prawnych. Podstawowym sposobem zazwyczaj jest zarejestrowanie znaku towarowego w odpowiednim urzędzie (w Polsce rejestracja przebiega w Urzędzie Patentowym RP), prawo do ochrony można też nabyć poprzez fakt używania 
znaku. Tak więc znaki towarowe dzielą się dodatkowo na zarejestrowane i niezarejestrowane [Załucki 2008].

Czemu rola znaków towarowych jest aż tak istotna w ochronie własności intelektualnej? Należy sobie uświadomić, że znak towarowy jest „twarzą” produktu/ /marki i ma za zadanie identyfikować i nadawać im indywidualny charakter, dodatkowo dywersyfikować podmioty względem konkurencji. Za pomocą znaków towarowych firmy mogą wzmocnić swoją postrzeganą wartość, stworzyć długoterminowe relacje $\mathrm{z}$ nowymi klientami oraz pielęgnować relacje $\mathrm{z}$ istniejącymi konsumentami [Airey 2009].

Odpowiednio chronione znaki towarowe mogą nawet same na siebie zarabiać. Można udzielać na nie licencji dla innych przedsiębiorców, np. w ramach sieci franchisingowej. Znak towarowy może być również przedmiotem sprzedaży, zamiany, darowizny, zastawu, może także stanowić zabezpieczenie zaciąganego kredytu oraz być podmiotem aportu do spółki [Adamczak, Gędłek 2009]. Łatwo zauważymy, jak istotny jest to obszar działania dla firm oraz pole dla potencjalnych naruszeń praw przez konkurencyjne przedsiębiorstwa.

\section{Jak działa prawo o ochronie znaków towarowych w praktyce? Interesujące przypadki}

Po przeanalizowaniu ustaw o prawie autorskim można wywnioskować, że twórca ma szereg narzędzi do ochrony swoich praw oraz może się czuć zabezpieczony przed większością prób wykorzystania jego własności intelektualnej. W wielu dziedzinach praktyka weryfikuje podstawy teoretyczne, często obnażając ich niedostatki. Nie inaczej jest w wypadku praw intelektualnych.

Jednym z najgłośniejszych przypadków ostatnich lat na polskim rynku była sprawa sądowa tocząca się przed Sądem Wspólnotowych Znaków Towarowych i Wzorów Przemysłowych pomiędzy Chocoladenfabriken Lindt \& Sprungli AG Szwajcaria a Terravita sp. z o.o. w sprawie zajączków wielkanocnych.

Sprawa może się wydawać dosyć zabawna, jednak zajączek firmy Lindt stał się jednym z najbardziej rozpoznawalnych w Europie symboli świąt Wielkiej Nocy oraz maskotką marki. Tym samym produkt spełnia wymagania prawne stawiane przed elementem mogącym stać się znakiem towarowym w rozumieniu prawnym. Terravita, korzystając z sukcesu marki Lindt, wprowadziła swoją wersję produktu, który również jest czekoladową reprezentacją siedzącego zajączka, z wyraźnie zaznaczonym rysunkiem nosa, wąsów, oczu, uszu i ogona, dodatkowo kopiując nawet wstążeczkę na szyi czekoladowego przysmaku. Całość kopii dopełniał fakt, że Terravita w materiałach marketingowych posługiwała się określeniem „zajączek Terravita”, co było łudząco podobne do określenia „zajączek Lindt”. Jak widać, firma Lindt miała wszystkie racjonalne podstawy, by wnieść pozew przeciw firmie Terravita. I wtedy nastąpiło szokujące dla wielu osób związanych z ochroną praw intelektualnych orzeczenie sądu: 

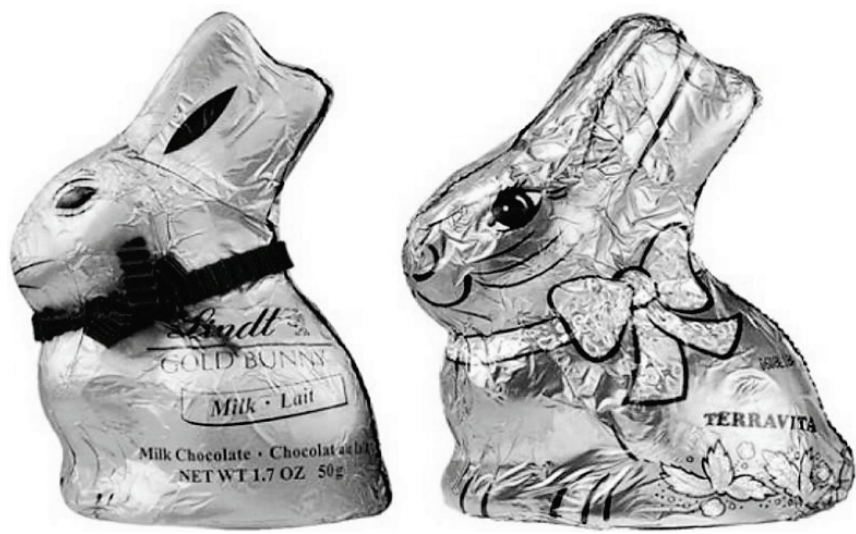

Rys. 2. Porównanie zajączków Lindt i Terravita

Źródło: [www.lindt.pl; www.terravita.pl...].

„Zdaniem Sądu Okręgowego podejmującego się oceny ewentualnego niebezpieczeństwa konfuzji z pozycji potencjalnego nabywcy wyrobów czekoladowych, gdyby nawet przyjąć, że porównywane wyroby (zająca Lindt i zająca Terravita) są prawie identyczne gabarytowo, to eksponowane na zajączkach słowa "Goldhase Lindt” i „Terravita” odróżniają w sposób istotny te wyroby. Przeciętny konsument nie ustala pochodzenia towaru jedynie na podstawie kształtu, formy zająca, lecz na podstawie innych istotnych elementów rozpoznawczych, w tym znaku słownego graficznego umieszczonego na wyrobie, koloru opakowania, jego ceny, znaku słowno-graficznego identyfikującego producenta. Jednocześnie sąd zaznaczył, że powód ma zastrzeżony kolor złoty, czerwony i brązowy, zajączek Terravita zaś występuje w kolorze srebrnym i jego cena jest znacznie niższa niż zajączka Lindt"’3. Bardzo interesującym elementem wyroku jest podniesienie aspektu ceny - ponieważ zajączek Lindt jest produktem z wyższej półki cenowej, zajączka Terravita ciężko pomylić z konkurencyjnym produktem. Tego typu uzasadnienie może doprowadzić do wielu problematycznych sytuacji w momencie, kiedy podróbka posiadać będzie znacząco niższą cenę od oryginału (a jest to nagminne). Sprawa Lindt vs Terravita rozeszła się szerokim echem wśród studiujących prawo i do dzisiaj często przytaczana jest jako studium przypadku na różnych uniwersytetach.

Sprawa ta doskonale ukazuje „płynność” praw chroniących autora. Teoretycznie wszystkie argumenty były po stronie firmy Lindt, jednak indywidualna interpretacja prawa doprowadziła do odrzucenia jego roszczeń.

Innym interesującym przykładem, zwłaszcza ze względu na kontekst plagiatowanego elementu, ale także i finał sprawy, jest logotyp dla miasta Białystok. W $2008 \mathrm{r}$. Białystok wyłonił $\mathrm{w}$ ramach przetargu firmę odpowiedzialną za przeprowadzenie wartej 2,7 mln złotych akcji promocyjnej miasta.

\footnotetext{
${ }^{3}$ Sygn. akt I ACa 1165/05, Wyrok w imieniu Rzeczpospolitej Polskiej z dnia 6 lipca 2006 r.
} 


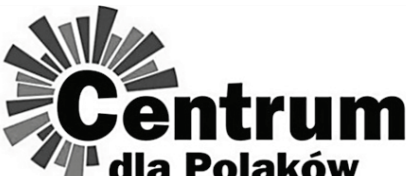

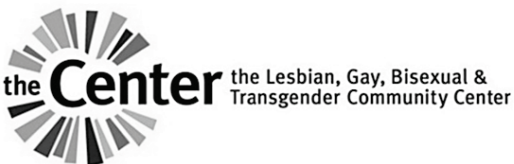

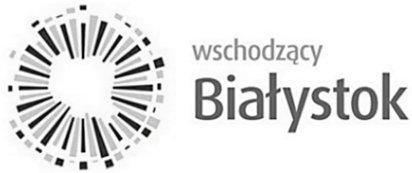

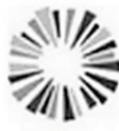

The Lesbian, Gay, Bisexual \& Transgender Community Center

Rys. 3. Porównanie podobnych logotypów stworzonych według jednej konwencji

Źródło: [Włoszczyński 2013].

Do zadań wybranej agencji (która notabene jest dużą agencją reklamową obsługującą znaczących klientów oraz nagradzaną na polskim rynku reklamowym) należało m.in. opracowanie nowego logotypu. Efekt finalny okazał się łudząco podobny do logotypu Stowarzyszenia lesbijek, gejów, biseksualistów oraz osób po zmianie płci. Pomimo walorów estetycznych, prawdopodobnie władze miasta chciałyby uniknąć tego typu bezpośrednich skojarzeń. Co interesujące w całej sprawie - zespół niezależnych ekspertów prawnych, powołany na okoliczność zbadania całej sprawy, jednoznacznie stwierdził, że nowy logotyp Białegostoku nie jest plagiatem. Logo udało się nieznacznie zmienić do formy, w której występuje obecnie. Pomimo zauważalnego podobieństwa, spełnia jednak zasadę o $20 \%$ różnicy względem innego znaku towarowego, tak by nie być posądzane o plagiat. Sprawa odbiła się jednak szerokim echem w mediach i mimo załagodzenia sytuacji z ujęcia prawnego, czarny PR pozostał.

\section{Możliwe kierunki działań w celu ograniczenia praktyki naruszania własności intelektualnej}

Przedstawione wyżej przykłady ukazują, że prawo autorskie może być „płynną” dziedziną i mocno zależeć od indywidualnych interpretacji organów sądowniczych. Skomplikowany system prawny, wysokie koszty postępowania na drodze sądowej oraz skomplikowane procedury prawne sprawiają, że wielu autorów nie wyciąga konsekwencji ani nawet nie dochodzi swoich praw.

Poszukując alternatywnych, w stosunku do ochrony prawnej, sposobów ochrony własności intelektualnej, warto przeanalizować skalę korzyści wynikających z wykorzystania cudzej własności intelektualnej do swoich celów. Z analizy wielu przypadków z praktyki działalności projektowej można wyróżnić trzy podstawowe sytuacje, w których następuje naruszenie cudzej własności intelektualnej: 
1. Projektant nieświadomie wykorzystuje cudzy projekt lub jego fragment. Może to uczynić całkowicie podświadomie, gdy projekt ten przelotnie widział, ale nie odnotował tego w swojej świadomości lub też działając całkowicie niezależnie, doszedł do identycznego (niemal) rozwiązania. Zamawiający w tej sytuacji najczęściej nie ma szans na wykrycie powstałego plagiatu i ingerencję $w$ tak powstały projekt.

2. Projektant świadomie wykorzystuje cudzy projekt, kopiując go w całości lub w pewnym zakresie. Ukrywa to przed zamawiającym, który podobnie jak w poprzednim przypadku, ma nikłą szansę wykrycia plagiatu, zwłaszcza jeżeli skopiowany projekt dotyczył innego obszaru działalności niż prowadzona przez zamawiającego.

3. Zamawiający oczekuje od projektanta opracowania projektu, który naśladuje istniejący już projekt (produkt) w celu wywołania u klienta skojarzenia z tym właśnie produktem. Projektant godzi się na taką działalność, świadomie naruszając własność intelektualną osób trzecich. Może przy tym wprowadzić drobne modyfikacje projektu, które ewentualnie pozwolą się obronić w razie sprawy sądowej.

W pierwszym przypadku zaistniała sytuacja przynosi jedynie straty. Projektant i zamawiający po ujawnieniu faktu wystąpienia plagiatu będą zgodnie dążyć do zmiany projektu. Skala niezbędnych nakładów z tym związanych uzależniona będzie od stopnia zaawansowania jego wdrożenia. Zazwyczaj koszt nowego projektu przejmuje na siebie projektant, natomiast zamawiający, jeśli jest przekonany o etycznej postawie projektanta, przejmuje na siebie przynajmniej część kosztów materialnych (materiały drukowane, koszt promocji). Zaistniała sytuacja, choć moralnie czysta, jeśli chodzi o intencje obu stron, może mieć swoje źródło w wadliwej organizacji sposobu współpracy między projektantem i zamawiającym, sprowadzającej się do złożenia zamówienia i odbioru gotowego projektu, często przy zbyt krótkich terminach na realizację zlecenia. W wielu wypadkach można by uniknąć nieświadomego plagiatu, gdyby proces dochodzenia do gotowego projektu odpowiednio wydłużyć, dając projektantowi odpowiednio więcej czasu na research wstępny, badania percepcji projektu przez dostatecznie liczną grupę osób czy też zbieranie opinii o jego różnych wersjach w środowisku projektantów. Szansę na unikalny projekt daje włączenie projektanta w proces powstawania firmy (marki, wyrobu), szczegółowe zapoznanie $\mathrm{z}$ oczekiwaniami i potencjalnym sposobem wykorzystania projektu $\mathrm{w}$ dalszych działaniach marketingowych. Podejście takie podnosi koszt projektu i wydłuża czas jego powstawania, ale daje podstawy do stworzenia produktu unikalnego, o wysokiej jakości i dużym potencjale wykorzystania w różnych sytuacjach marketingowych.

W drugim przypadku mamy do czynienia z nieetyczną postawą projektanta, której celem jest znaczne obniżenie nakładu pracy na projekt. Projektanci uciekają się do takich metod najczęściej wówczas, gdy nie widzą szans na pokrycie przez zamawiającego rzeczywistych kosztów opracowania utworu w pełni oryginalnego, wytworzonego w rezultacie długotrwałego procesu projektowego. Wstępnym sygnałem, że taka sytuacja ma miejsce, jest procedura wyłonienia projektu $\mathrm{w}$ formie 
konkursu lub przetargu. Jeżeli przy tym zamawiający żąda szczegółowej oferty, a jedynym kryterium wyboru oferty jest cena, to część projektantów odbierze to wręcz jako zachętę do skrajnie oszczędnego podejścia, jeśli chodzi o nakład pracy. Ochrona prawna zawartości intelektualnej oferty jest na skandalicznie niskim poziomie, a przypadki wyboru najtańszego oferenta, któremu zleca się realizację projektu w oparciu o koncept zawarty w innej, odrzuconej z racji ceny ofercie, są o wiele częstsze niż plagiat chronionego prawnie znaku towarowego. Środowisko projektantów ma tego świadomość, a dla części z nich takie podejście zamawiającego jest odbierane jako przyzwolenie na nieetyczne postępowanie. W efekcie takiego działania zamawiający otrzymuje produkt korzystny cenowo, ale o nikłej wartości, oderwany od pogłębionej analizy strategii marketingowej firmy, a być może zupełnie bezużyteczny w momencie, gdy plagiat wyjdzie na jaw. Korzyść projektanta może również okazać się pozorna, zwłaszcza w zestawieniu z ryzykiem narażenia się na postępowanie sądowe, które może zainicjować zarówno oszukany zamawiający, jak i poszkodowany twórca lub właściciel przywłaszczonego projektu. Projekt taki jest ponadto nieprzydatny dla projektanta do promowania się w formie portfolio.

Jeżeli zamawiający produkt $\mathrm{z}$ obszaru komunikacji wizualnej ma na uwadze uzyskanie unikalnego utworu wysokiej jakości, który będzie integralną częścią wizerunku firmy, to korzystnie jest uszanować uświęcone tradycją podejście, polegające na wyłonieniu projektanta na podstawie jego portfolio oraz opinii innych klientów odnośnie do jego stylu pracy i obdarzyć zaufaniem w zakresie kompetencji i przebiegu procesu twórczego. W ten sposób środowisko eliminuje osoby o złej opinii, nieetyczne, nastawione na szybki, powierzchowny, choć pozornie estetyczny efekt.

Sytuacja trzecia zakłada zgodne, nieetyczne postępowanie zamawiającego oraz projektanta. Podstawą jest tutaj zapewne zupełny brak poszanowania przez zamawiającego własności intelektualnej $\mathrm{w}$ formie projektu. Towarzyszy temu również brak wiary w możliwość samodzielnego wykreowania wartościowego, unikalnego produktu i zapewnienia mu sukcesu rynkowego. Projektant nakłoniony do współudziału w takim procederze może „zabezpieczyć się”, wprowadzając niewielkie zmiany, które pozwolą na uzyskanie korzystnego ewentualnego wyroku sądowego. Zamawiający otrzymuje więc dokładnie to, co zamierzył - produkt przypominający pierwowzór. Projektant otrzymuje wynagrodzenie z zasady znacznie niższe niż wynikające $\mathrm{z}$ opracowania unikalnego utworu, gdyż zamawiający jest świadom jego niskiego nakładu pracy. Kluczem do ograniczenia przedstawionej praktyki wydaje się być rozbicie solidarności zamawiającego i projektanta w nieetycznym postępowaniu poprzez wskazanie niewspółmiernie małych korzyści dla projektanta oraz potencjalnych strat $\mathrm{w}$ postaci poważnego uszczerbku w reputacji, co często zamyka drogę do przyszłych intratnych zleceń. Niestety, może to się okazać zawodne w przypadku projektantów pozbawionych ambicji artystycznych oraz osób, które sporadycznie wykonują usługi projektowe, bez przygotowania zawodowego w postaci wykształcenia artystycznego. 
Z przeprowadzonych analiz poszczególnych sytuacji można wysnuć wniosek, że projektant osiąga maksymalną korzyść w przypadku, gdy zrealizuje on w pełni oryginalny projekt, powstały w rezultacie odpowiednio długiego i prowadzonego z należytą starannością i wnikliwością procesu projektowego. Odpowiednio silne zaangażowanie emocjonalne w projekt stwarza również szansę na unikalny efekt artystyczny. Taki projekt uprawnia twórcę do odpowiednio wysokiego wynagrodzenia oraz dostarcza mu możliwości promocji i uzyskania kolejnych atrakcyjnych zleceń.

Zamawiający osiąga maksymalną korzyść w sytuacji, gdy otrzyma unikalny, wartościowy pod względem artystycznym projekt, dający podstawę do skutecznych działań marketingowych. W wysokim potencjale projektu należy upatrywać możliwości zwrotu poniesionych na niego nakładów. Zamawiający z reguły staje się właścicielem majątkowych praw autorskich do utworu i to jemu przypadają korzyści $\mathrm{z}$ jego wykorzystania. Zamawiający dysponuje pełną swobodą wyłonienia projektanta, któremu powierzy zlecenie i od niego zależy, jaką przyjmie procedurę. Nie zawsze jednak dysponuje niezbędną wiedzą co do konsekwencji, jakie może to pociągnąć w odniesieniu do jakości projektu. Sprawdzona w obszarze komunikacji wizualnej procedura wyłonienia projektanta na podstawie jego dotychczasowych dokonań prezentowanych $\mathrm{w}$ portfolio, stylu pracy i opinii w środowisku stwarza znacznie większą szansę na wartościowy projekt niż przetarg czy konkurs. Świadomość tego nie jest dostatecznie powszechna. Jeżeli przy tym zamawiający wykaże odpowiednio duże zaangażowanie w przekazanie swoich indywidualnych preferencji marketingowych przy pozostawieniu twórcy pełnej swobody artystycznej, to uzyska niemal gwarancję wartościowego, adekwatnego do nakładów projektu. Ponadto zaangażowanie $\mathrm{w}$ proces powstawania projektu daje pełniejszą wiedzę na temat celowości i wysokości ponoszonych w tym zakresie nakładów.

Z kolei każda sytuacja, w której dochodzi do plagiatu, nie umożliwia uzyskania potencjalnie maksymalnych korzyści zarówno dla projektanta, jak i zamawiającego. Uświadomienie tego faktu może stanowić ważny argument w walce z praktyką naruszania własności intelektualnej. W obszarze komunikacji wizualnej, w specyficznej dziedzinie leżącej na pograniczu sztuk pięknych i marketingu, operowanie plagiatem, a więc niepełnowartościowym, a w pewnych okolicznościach bezużytecznym projektem, stwarza słabe podstawy do osiągnięcia sukcesu komercyjnego. Trudno sobie bowiem wyobrazić strategię marketingową opartą na wizerunku kojarzonym z inną instytucją, w oczywisty sposób nieoryginalnym, która nie prowadzi do narażania się na śmieszność i utratę klientów. Tak można działać wyłącznie na rynku tzw. podróbek, gdzie obowiązują zresztą zupełnie inne prawa.

\section{Podsumowanie}

Ochrona prawna utworów z obszaru komunikacji wizualnej nie daje gwarancji poszanowania własności intelektualnej. Orzecznictwo napotyka problemy, u podstaw których leży uznaniowy charakter oceny oryginalności utworów artystycznych. 
Przedstawione studia przypadków ilustrują ten stan w sposób dobitny. Wielu autorów nie wchodzi na drogę prawną w wypadku plagiatu ich projektów ze względu na niepewny efekt postępowania i kłopotliwy, a bywa, że i kosztowny proces.

Wskazano więc na inne możliwości ograniczenia praktyki naruszania własności intelektualnej, ukazując potencjalnie większe korzyści wynikające z postępowania etycznego, zgodnego z prawem, a przy tym efektywnego ekonomicznie. Kopiowanie utworów z obszaru komunikacji wizualnej nie prowadzi do korzyści podobnych, jakie w obszarze techniki daje kradzież technologii czy „obchodzenie” patentów.

Po początkowej, spontanicznej fazie wzrostu dziedzina komunikacji wizualnej wchodzi w okres kształtowania się wzorców zachowań, również etycznych. W dobie rosnącej konkurencji zaczynają się liczyć nie tylko talent i kompetencje artystyczne projektanta, ale również preferowany przez niego modelowy proces projektowy oraz opinia w środowisku. Jest też miejsce na ocenę etyczności zachowań projektantów i włączenie tej oceny w proces ich wyboru przez zamawiającego. Postawa projektanta ma bowiem kluczowe znaczenie w unikaniu sytuacji naruszenia cudzej własności intelektualnej.

Trendem gospodarczym staje się powoli personalizacja produktu z maksymalnym dostosowaniem go do indywidualnych potrzeb klienta. Ten kierunek będzie prowadził do wyraźnego zwiększenia się unikatowych projektów, wymuszając na systemie prawnym uproszczenie procedur rejestracji i skuteczności egzekwowania prawa autorskiego. Znajdzie to prawdopodobnie również odzwierciedlenie w ustawie odpowiedzialnej za znaki towarowe - co może pozwalać w sposób pozytywny patrzeć w przyszłość ochrony własności intelektualnej w obrębie komunikacji wizualnej.

\section{Literatura}

Adamczak A., Gędłek M., Znaki towarowe w działalności małych i średnich przedsiębiorstw, Krajowa Izba Gospodarcza, Warszawa 2009.

Airey D., Logo Design Love: A Guide to Creating Iconic Brand Identities, New Riders, 2009.

Barta J., Czajkowska-Dąbrowska M., Ćwiąkalski Z., Markiewicz R., Traple E., Prawo autorskie i prawa pokrewne. Komentarz, Wydawnictwo Zakamycze, Kraków 2005.

Michniewicz G., Ochrona własności intelektualnej, Wydawnictwo C.H. Beck, Warszawa 2012.

Sieńczyło-Chlabicz J., Banasiuk J., Zaręba J., Zawadzka Z., Prawo autorskie, [w:] Prawo własności intelektualnej, red. J. Sieńczyło-Chlabicz, Wydawnictwo LexisNexis, Warszawa 2009.

Popularyzacja wiedzy z zakresu własności intelektualnej poprzez działania promocyjne, http://www. wlasnosc-intelektualna.pl (dostęp: 06.04.2013).

System prawa prywatnego. Prawo autorskie, red. J. Barta, Wydawnictwo C.H. Beck, t. 13, Warszawa 2007.

Ustawa z dnia 4 lutego 1994 r. o prawie autorskim i prawach pokrewnych, DzU $1994 \mathrm{nr} 24$ poz. 83.

Ustawa z dnia 30 czerwca 2000 r.o prawie własności przemysłowej, DzU 2001 nr 49 poz. 508

Włoszczyński A., Wschodzacy Gaycenter, http://www.alw.pl/2008/12/wschodzacy-gaycenter/ (dostęp: 25.06.2013).

www.lindt.pl; www.terravita.pl (dostęp: 25.06.2013).

Zajączkowski M., Podstawy innowacji i ochrony własności intelektualnej, Wydawnictwo Economicus, Szczecin 2003. 
Załucki M., Licencja na używanie znaku towarowego: studium prawno-porównawcze, Wolters Kluwer Polska, 2008.

Załucki M., Pojęcie prawa własności intelektualnej i jego miejsce w systemie prawnym, [w:] Prawo własności intelektualnej. Repetytorium, red. M. Załucki, Difin, Warszawa 2008.

\section{PROTECTION OF INTELLECTUAL PROPERTY RIGHTS IN THE FIELD OF GRAPHIC DESIGN}

Summary: The purpose of this article is to present specific problems related to the violation of intellectual property in the field of visual communication and an attempt to identify more effective ways to protect it. Legal protection works in the area of visual communication do not guarantee respect for intellectual property. Jurisprudence encounters problems at the core of which is the discretionary nature of the assessment of the originality of artistic works. The article presents case studies that illustrate this state very clearly. Many artists do not enter a legal challenge in the case of plagiarism of their projects because of the uncertain effect of the procedure and troublesome and sometimes even expensive process. In case of violation of someone else's intellectual property rights in respect of the works belonging to the area of visual communication the attitude of the designer is essential. Very important are also circumstances in which there is a breach of intellectual property. The analysis of these circumstances can be a starting point to searching for effective ways to prevent the infringement of intellectual property, with particular emphasis on the indication of the illusory benefits of this practice, obtained in such a specific field as visual communication. Possible courses of action in order to reduce the practice of intellectual property violations were proposed. The analysis of these measures is based on the concept of searching for the maximum benefit that can be achieved in co-operation of the designer with the customer. The analyses of individual situations lead to a conclusion that the designer has a maximum benefit when he fully realizes the original design, created as a result of a reasonably long and conducted with due diligence and thoroughness of the design process. Accordingly, strong emotional involvement in the project also creates a unique opportunity for artistic effect. Such a project, entitles the creator to a sufficiently high salary and provides him with an opportunity to promote and achieve further attractive orders. The customer has a maximum benefit in a situation when he receives a unique design, valuable in terms of art, that gives rise to the effective marketing activities. In the high-potential project the opportunities of reimbursement for the costs should be sought. The sphere of visual communication enters a period of formation of the patterns of behavior, including ethical ones. In an era of increasing competition not only the talent and artistic competence of the designer begins to count, but also the model of design process preferred by him and an opinion about him in the environment. It is also the place to assess the ethical behavior of designers and include it into the evaluation process of their selection by the customer. The attitude of the designer is of vital importance to the avoidance of a violation of intellectual property of somebody else. Equally important is the correct relationship between the designer and the customer. A personalization of the product with the maximum adaptation to individual customer needs is becoming an economic trend. This trend will lead to the increase of number of significantly unique projects, forcing the legal system to simplify the procedures for the registration and enforcement of copyright law. This will be probably also reflected in the Act responsible for trade marks - which can allow a positive look to the future of protection of intellectual property within the visual communication.

Keywords: intellectual property, graphic design, copyrights law, trademarks. 